\title{
Imitating English Oral Texts: A Useful Tool to Learn English Pronunciation?
}

\author{
AMPARO LÁZARo IBARRola \\ Universidad Pública de Navarra
}

Received: 5 April 2010 / Accepted: 28 November 2010

ISSN: $1697-7467$

\begin{abstract}
This is a report on a specific methodological intervention to improve the pronunciation of 15 Spanish students of English. For 14 weeks, the students were trained in the imitation of English recordings (from films and TV series). One initial (at week 1) and one final (at week 14) imitation, as well as a free speech delivered by every student (at week 14), were analysed. The results indicate that the students slightly improved their pronunciation when imitating but were unable to transfer the gains to their free speech. Students' impressions were also investigated. All students found the activity helpful and motivating.
\end{abstract}

Keywords: reading aloud; oral text imitation; teaching pronunciation; teaching English.

\section{La imitación de textos orales ingleses: ¿una herramienta útil para aprender la pronunciación inglesa?}

RESUMEN: Este trabajo presenta una intervención metodológica concreta para mejorar la pronunciación de 15 aprendices españoles de inglés. Durante 14 semanas los alumnos escucharon e imitaron extractos de series y películas en inglés. El análisis de datos incluye una imitación inicial (semana 1), una final (semana 14) y un pequeño discurso libre (semana 14) de cada alumno. Los análisis parecen indicar una leve mejora de la pronunciación en la imitación de textos pero cuyas características no parecen transferirse al discurso libre de los alumnos. Por otra parte, los alumnos explicaron que la actividad les había resultado útil y motivadora.

Palabras clave: lectura en voz alta; imitación de textos orales; enseñanza de la pronunciación; enseñanaza del inglés.

\section{INTRODUCTION}

The acknowledgement that good pronunciation plays a paramount role in the acquisition of a foreign language is nowadays undisputed. There also exists an impressive wealth of empirical research showing that instruction has beneficial effects on pronunciation. Likewise, there is an equally impressive profusion of pedagogical works focusing on teaching pronunciation. Paradoxically, recent works dealing with pronunciation issues in English as a Foreign Language (EFL) agree that this growing volume of empirical and pedagogical works does not seem to 
make a significant difference in many classrooms, where the teaching of pronunciation still remains scarce or even consigned to oblivion (Barrera Pardo, 2004; Brown, 1991; Samuda, 1993; Walker, 1999).

The present paper presents a small scale pilot study which tests the value of a very specific methodological intervention to improve the English pronunciation of a group of 15 Spanish university students. During 14 weeks the students were provided with a wide range of recorded texts (mainly from films and TV series). They simply had to listen to them carefully and imitate them, that is, they had to read the texts aloud imitating the pronunciation of the original recordings and focusing on connected speech features and intonation. At the end of the course they were also asked to speak freely about a topic of their choice (approx. 1 minute). This was used to analyse if the students were able to transfer the pronunciation features used in the imitations to their own natural speech.

Reading aloud is not a new activity, «for a large number of teachers worldwide reading aloud constitutes a staple of the classroom diet» (Gabrielatos, 2002: 1) and several researchers have recently enhanced its value for the classroom (Birch, 2002; Gibson, 2008). However, the methodological intervention proposed in the present study differs from what we traditionally understand as reading aloud in two aspects:

(i) The texts are recorded extracts from films or television series.

(ii) Students listen to and imitate the recordings as many times as they need before reading the texts aloud.

Contrary to some textbook recordings, extracts from films and TV series provide natural and contextualized speech samples. Also, using this type of texts is probably more motivating for the students than simply using textbooks. It is thus our belief that both innovations make the reading aloud activity useful, attractive and challenging. In addition, this activity does not mean heavy workload for teachers. Therefore, our proposal offers an alternative for those teachers who already use reading aloud activities in the traditional sense as well as for those teachers who simply wish to introduce new pronunciation tasks in their teaching practice.

\section{Teaching pronunciation}

\subsection{Deficiencies}

Despite the great variety of methodologies and approaches to language teaching (see Richards \& Rodgers, 2001 for a review) it could be said that direct pronunciation teaching has only played a major role with the audio-lingual and direct methods. As a reaction against the artificiality of the grammar-translation method, these two methods attached great importance to pronunciation and achieved very important goals in this respect. Thus, a milestone was marked: the paramount role of pronunciation was being acknowledged for the first time in the history of foreign language methodologies. However, with the rise of the communicative approach in the late 70s (Brumfit and Johnson, 1979; Widdowson, 1978), these methods were harshly criticized for having ignored the communicative value of languages and fell out 
of general favour. The growing popularity of the communicative approach rapidly pushed pronunciation teaching back to oblivion for the sake of communicative value. This approach did not ignore the importance of pronunciation, as had been the case with the grammartranslation method, but it simply subordinated pronunciation to general communicative skills. In short, pronunciation per se stopped being taught; instead it was assumed that students would pick up the pronunciation while learning to communicate in the language. No matter how intuitive, this assumption collides with research data showing that bad pronunciation is usually the main reason for communication breakdowns among EFL students (Celce-Murcia et al. 1996). Herein lies the paradox of the communicative approach: intelligible pronunciation is a sine qua non condition for oral communication (Jenkins, 2000) and the communicative approach, whose main aim is successful communication, neglects to teach it.

Still stemming from communicative approaches, some current EFL courses often relegate pronunciation «to a subsidiary role of broader language performance skills such as speaking and listening» (Barrera Pardo, 2004:6) and, to make matters worse, the speaking skills often deserve little attention in the EFL classrooms, especially and not surprisingly, in large ones.

If we move now to phonology courses, for several decades of the $20^{\text {th }}$ century, English phonology courses and manuals have been primarily focused on a thorough analysis of the foreign language sound segments (phonemes) and on gaining a good command of transcription (Barrera Pardo, 2004; Derwing \& Munro, 2005; Murphy, 1997). Accordingly, students enrolled in phonology courses are able to transcribe and define sounds but they might not be so able to pronounce those phonemes, since they are not specifically trained in pronouncing them. In addition, this segmental focus has neglected the teaching of suprasegmental features (intonation, rhythm and stress) ignoring a great bulk of research which has shown that these features are more crucial to successful communication than the segments (Anderson-Hsieh, 1992; Boyle, 1987; Brazil, 1997; Dalton \& Seidlhofer, 1994; Leather, 1983; Liberman, 1967; Moyer, 1999; Munro \& Derwing, 1995, 1998, 2001; Pennington, 1989; Pennington \& Richards, 1986). It seems that «pedagogy is rather slower to adapt with respect to innovations relating to pronunciation than those relating to other linguistic levels» (Jenkins, 2004:110). In conclusion, many phonology courses are very theoretical, are mainly focused on segmental analysis and devote little attention to suprasegmental features or speech practice. In other words, they teach about pronunciation but they do not teach students to pronounce. As it was the case with general communicative skills, it should not be assumed that the phonological background will automatically mean better pronunciation.

\subsection{Achievements}

As stated above, the focus on pronunciation seems to be marginalised in EFL classrooms. Similarly, applied phonology is rarely taught at schools or universities. However, far from nothing being done, there are growing, strenuous and ongoing efforts to put focus on the teaching of pronunciation (see for example Gilbert, 2008). It could be said that the achievements have been great (probably greater in ESL settings) but have not always reached the hands of classroom teachers. As a result, while some English teachers are successful in assisting their students with pronunciation, many often lack training and confidence to teach pronunciation and therefore neglect this area (Derwing \& Munro, 2005). Nevertheless, techniques and methods are constantly developed and pronunciation courses are also growing. This can be 
well illustrated by the establishment of the TESOL Interest Section for Speech, Pronunciation and Listening (SPLIS) in 1996. The methodological intervention reported here is consistent with and contributes to these efforts.

On the other hand, it is also important to clarify that both general EFL courses training on general oral communication skills and general phonology courses assist pronunciation. In fact, it is beyond the aims of the present work to pin down the validity of such approaches. We just want to make it clear that they focus on something else (general oral skills or phonology) and pronunciation can be acquired on the way but is not placed at the heart of teaching.

With the present proposal, reading aloud imitating native speakers, we wish to test the value of a specific task whose main aim is to improve students' pronunciation. This proposal simply offers another tool for teachers and does not compete with transcription or speaking activities. On the contrary, it is just one more alternative in the colourful mosaic of activities that can help students with the complexities of English pronunciation.

\section{The ROLE OF READING ALOUd AND OF IMITATION}

With few exceptions (Gibson, 2008) general EFL teaching methodology does not recommend reading aloud. The reasons argued can be encapsulated in the general idea that reading aloud is not focused on comprehension and therefore is not a valid technique for developing reading skills (Dwyer, 1983; Grabielatos, 2002). As a matter of fact, students can read aloud correctly without understanding what they are reading (Wallace, 1992). However, in the present work we do not advocate the use of reading aloud with the purpose of teaching reading but with the only purpose of teaching pronunciation. Therefore we will not concentrate on reading comprehension but on correctly sounding out the words. Also, and as explained in the introduction, in the present study we are not referring to reading aloud in the traditional sense. In contrast, and very much along the lines of the direct method, we refer to students reading texts aloud after having listened to and imitated those texts as many times as necessary.

We would also like to emphasize the naturalness of the selected recordings that students imitate, since they are excerpts from films and TV series. This stands in contrast with the unnatural texts often used in traditional reading activities (Celce-Murcia et al., 1996) that have been frequently tagged as dull, boring and artificial (Gibson, 2008).

In conclusion, it is our belief that reading aloud, as operationalized in this work, offers advantages both at a purely linguistic level and at the level of motivation. In the following subsections and following Gibson (2008), we would like to emphasize those advantages which have been previously highlighted for reading aloud activities and which are of particular interest for the present work.

\subsection{Reading aloud reinforces grapho-phonemic correspondences.}

It is widely recognized that L1 language transfer is a factor in virtually every aspect of L2 learning (Gass \& Selinker, 1983; Kellerman \& Sharwood Smith, 1986). On the other hand, languages differ greatly in how they represent phonological information in the writing system. Consequently, research has shown that the first language orthographic experience 
exerts a great influence on decoding the written form of a second or foreign language (Akamatsu, 1999, 2002; Koda, 1989, 1990, 1999, 2000; Hamada \& Koda, 2008; Perfetti \& Liu, 2005; Wang, Koda, \& Perfetti, 2003).

Similarly, Spanish EFL students usually learn the correspondences between the letters and sounds of their own language (they learn to read) at a very early age. When they start reading English texts, they initially transfer the Spanish orthographic properties significantly affecting both pronunciation and reading comprehension. Gradually, students are corrected on the spot and they are able to discover the differences between their native tongue and English and to infer the very complex grapho-phonemic rules of the English language (Avery \& Ehrlich, 1992; Lázaro Ibarrola, 2007). However, this process is hard and pervasive interferences from the written text are often found in the pronunciation of EFL students ${ }^{1}$. In fact, the transferred L1 grapho-phonemic rules continue to evolve through L2 print processing experience and the resulting L2 decoding competence reflects both L1 and L2 orthographic properties (Hamuda \& Koda, 2008). Bryson (1990) explains this complexity by comparing spelling and pronunciation in English to trains on parallel tracks, one sometimes racing ahead of the other before being caught up.

To assist learners in this difficult process, Gibson (2008) emphasizes the fact that reading aloud reinforces grapho-phonemic correspondences. Likewise, the reading task that we propose here could serve as a great help for the students in their struggle to establish the correct connections between written and oral English.

\subsection{Reading aloud aids the acquisition of prosodic features}

A second purported advantage of reading aloud is that it aids the acquisition of prosodic features (Beaken, 2009; Gibson, 2008). Ongoing research on intonation, initiated by the various works by David Brazil in the 1970s, has gradually enhanced the important role of prosody in successful communication. In fact, suprasegmental features have been claimed to very strongly affect comprehensibility, even more strongly than segmental features (Derwing \& Rossiter, 2003; Gibson, 2008). Paradoxically, the works that have set out to research the acquisition of suprasegmentals are still scarce (Chun, 1988, 2002; Trofimovich \& Baker, 2006) and so are the teaching materials focused on these features (Gilbert, 2008). Generally speaking, EFL/ESL manuals designed to teach pronunciation devote their attention to the segmental aspects of the language and neglect the focus on suprasegmentals (Dalton \& Seidholfer, 1994) ${ }^{2}$.

The lack of attention to suprasegmentals is easily explained by the simple and widely acknowledged fact that suprasegmentals are extremely important but extremely difficult to teach (Celce-Murcia, 1987; Roach, 1991). Some authors and teachers hold the extreme view that prosodic features are not teachable and refer to intonation as «the problem child of pronunciation teaching» (Dalton \& Seidlhofer, 1994:76). In addition, psychological factors have been claimed to negatively affect the acquisition of speechrhythms. These aspects are deeply-rooted in the L1 and students «feel uneasy when they hear themselves speak with the rhythm of a second language (L2)» (Gibson, 2008:1).

\footnotetext{
${ }^{1}$ Obviously, pronunciation difficulties are not just related to interference from the written text.

${ }^{2}$ Note, however, that some recent works have made great efforts to integrate these features in the teaching of pronunciation (see Gilbert, 2008).
} 
Consequently, EFL classroom practices have often disregarded the teaching of prosodic features even more than the teaching of pronunciation in general. If pronunciation in general has been pushed to the background of EFL classrooms, prosodic or suprasegmental features have been pushed to the background of the background. The specific task reported here can help students to become aware of, and to train themselves in, this forgotten yet crucial aspect of the English language.

\subsection{Other reasons}

According to Gibson (2008) reading aloud also helps anxious students to feel more able to speak. It seems that controlled speech (imitative) activities are less distressing than free spontaneous speech. Also, reading aloud has been claimed to be very appropriate for autonomous learning (Stevick, 1989) and therefore an excellent tool for lifelong learning.

On the other hand, logistical advantages should not be disregarded. Reading aloud is not demanding in terms of time preparation for the teacher, it is attainable for those students who lack basic phonological knowledge and it can be very motivating if students are allowed to imitate texts chosen on the basis of their own interests. Nowadays, thanks to new technologies, recordings of English texts of all kinds are easily accessible and this wide range of recordings can also include different English accents.

To finish this section, once the advantages have been emphasized, it is necessary to address a crucial question: how will the above purported benefits of reading aloud transfer to students' free speech? In other words, it would be necessary to analyse whether the prosodic and segmental features that students are said to develop in text reading are really internalised and remain when students are asked to speak freely.

\section{ReSEARCH QUESTIONS}

The present work sets off to measure the effectiveness of a reading aloud activity on the pronunciation of 15 Spanish learners of English. The reading activity was based on the imitation of original English recordings selected from TV series and films. The purpose when choosing these texts was two-fold: to use extracts of natural speech and to make the activity motivating for the students.

Accordingly, our basic research question is whether this activity will improve students' pronunciation. On the basis of the review of previous literature referred to above, we entertain the general hypothesis that this task will have a positive effect on the students' overall pronunciation (including segmental and suprasegmental features). A subsequent question would be to decide whether this expected improvement remains limited to the texts the students are imitating or whether they will be able to transfer the improvements to their spontaneous speech.

In addition, we also made an attempt to investigate students' impressions. Even if students' impressions do not necessarily coincide with real achievements, the long acknowledged importance of students' self-confidence and motivation when learning a language (Gardner \& Lambert, 1959; Gardner, 1982) justifies the incorporation of this question. 
In summary, our research questions are the following:

(i) Will the students improve their pronunciation from R1 to R2?

(ii) If the students improve their pronunciation when reading, will they be able to transfer the improvements to their FS?

(iii) Will the students find the reading aloud activity useful as a tool to improve their pronunciation?

\section{Methodology}

\subsection{The participants}

The participants were 15 20-year-old Spanish university students (13 females, 2 males) enrolled in a Phonology Course. They all followed the same Teacher Training Programme for EFL Primary School Teachers at a Spanish University. According to internal university tests their level was equated to a B2 level following the Common European Framework of Reference for Languages (2001).

\subsection{Course description}

The course lasted 14 weeks and devoted one hour per week to providing students with a basic knowledge of English Phonology and two hours per week to a practical workshop. In the practical workshop the students were provided with recordings of English oral texts. Their training simply consisted in listening to the texts carefully and imitating them, that is, they had to read the texts aloud imitating the pronunciation of the original recordings. They trained on their own during the week and met with the teacher in class once a week to read the texts aloud.

\subsection{Data collection}

This study consists of a one group pre-test/post-test design. The following three recordings and one questionnaire were collected from each student:

Recording 1-Reading 1: Week 1. During the first week of the course every student was asked to record one extract from a film or TV series in English (approx. 1 minute $)^{3}$. The students had to provide the transcript, that is, the exact written copy of the oral recording (usually they did so with the help of subtitles). They also had to show both the recording and the transcript to the researcher who made sure that they had obtained an accurate written version of the recording. Then, they had to read it out imitating the original text as much as possible as regards segmental and suprasegmental features. This reading was recorded. We will refer to this recording as Reading 1 (henceforth R1).

\footnotetext{
${ }^{3}$ Obviously, this recording had to be different to the recorded texts used for training in the workshops.
} 
Recording 2-Reading 2:Week 14. At the end of the course all students were asked to re-read R1 in order to analyse their improvement. This recording will be referred to as Reading 2 (henceforth R2).

Recording 3-Free Speech: Week 14. Also, at the end of the course, all students were asked to speak freely about a topic of their choice for one minute. This speech was also recorded. We will refer to this third recording as Free Speech (henceforth FS).

Individual questionnaire: Finally, the participants were asked to fill in a questionnaire with their own impressions about the usefulness of the reading task for the improvement of their pronunciation of English. They had to choose between 1 (not useful); 2 (a bit useful): 3 (quite useful); 4 (very useful).

To avoid the negative effects of anxiety the students recorded all the texts (R1, R2 and FS) at home. Also, when the task was finished the students discussed their impressions with the teacher in a 30-minute group session.

\subsection{Evaluators}

Four independent native speakers of English evaluated the students' recordings. The evaluators were four 20-year-old English students enrolled in Primary Education courses at an English university. Three of them spoke no Spanish at all and one had a very low command of this language. The evaluators listened to R1 and R2 from every student subsequently but in a random order. They had to rate both recordings based on a 1 to 5 rating scale. They were told to simply judge based on overall impressions as regards the intelligibility and good pronunciation of the recordings. They were told not to concentrate on giving a specific mark on the 1 to 5 scale, but to concentrate on whether one recording was better than the other ${ }^{4}$ Once they had rated both readings, they listened to the FSs and they were also asked to mark them on the 1-5 scale deciding if these were they were better or worse than the readings. Finally, their overall impressions were also discussed in a final 30-minute interview with the researcher.

\section{RESUlts}

\subsection{Will the students improve their pronunciation when reading?}

When R1 and R2 were compared the four evaluators agreed that most students did better at reading 2. Figure 1 shows group results.

${ }^{4}$ While holistic measures of pronunciation have been criticized for offering very vague notions (Underhill, 1987) they seem to be effective for categories which are hard to define, such as naturalness of speech and native-like language use, and are therefore advocated by many researchers (e.g. Celce-Murcia et. al., 1996; Hughes, 1991; Koren, 1995). Also, holistic ratings based on overall impressions suit our purpose of comparing R1 and R2. In fact, we decided to avoid descriptors for every score (such as the ones used in Cambridge examinations) because we were only interested in the comparison of R1 vs. R2 rather than on students reaching a specific score. 


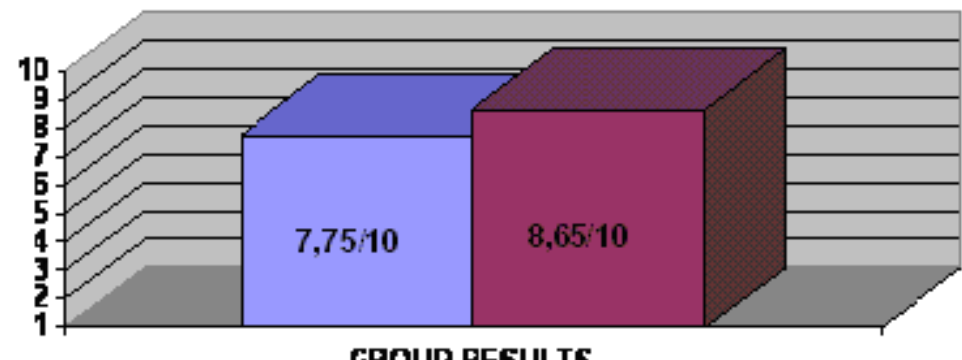

GROUP RESULTS

\section{DREADING 1 QREADING 2}

Figure 1: Group results: R1 vs. R2 (1-10 scale)

These results seem to lend support in favour of our hypothesis that the reading aloud practice would improve the students' pronunciation when reading. However, we need to qualify this finding with the analysis of individual results. Figure 2 shows the individual scores per participant.

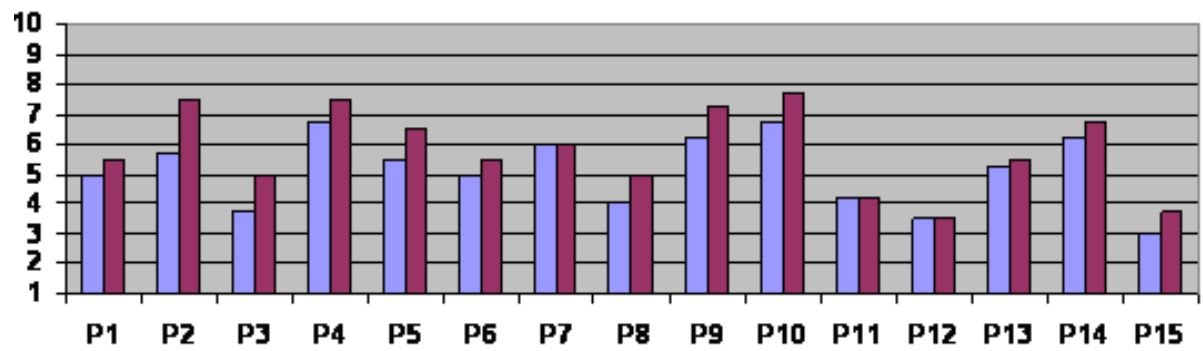

\section{QREADING 1 ロREADING 2}

Figure 2: Individual results: $R 1$ vs. $R 2$ (1-10 scale)

As can be seen in figure 2, the differences between R1 and R2 are sometimes very small and three participants (P7, P11, P12) obtained similar scores in both readings. This means that there seems to be a tendency to improve but we have to be very cautious and call for more research which includes longer training and larger pools of participants to further explore these very preliminary impressions.

\subsection{If the students' pronunciation when reading improves, will they be able to transfer the improvements to their FS?}

As regards FS, the scores students obtained in their FSs are sometimes lower (7 participants), sometimes similar (4 participants) and sometimes higher (4 participants) than the ones they obtained in R2, as we show in figure 3 where we present individual scores. 


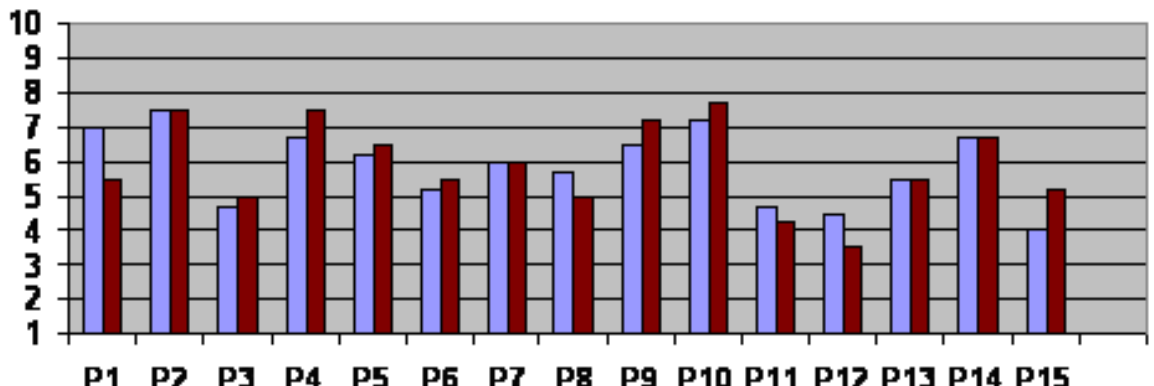

P1 P2 P3 P4 P5 P6 P7 P8 P9 P10 P11 P12 P13 P14 P15

\section{口 SPEECH QREADING 2}

Figure 3: Individual results: FS vs. R2 (1-10 scale)

The evaluators' overall impressions (expressed in their interview with the researcher) help to interpret these conflicting ratings. All four evaluators agreed that for some speakers the imitations (R1 \& R2) sounded more English-like in terms of intonation and rhythm, yet their FS was more intelligible. In other words, the evaluators found a discrepancy between native-like prosodic features and intelligibility. This explanation offers a potential answer for our second research question. According to the evaluators' impressions some students did not seem to be able to transfer the suprasegmental features from the reading to their FSs. A similar finding was reported by Barnes (1988) who observes that when his students were doing «say it after me» exercises they «repeated the patters accurately, but seldom used them in their free conversations» (Barnes, 1988:17). On the other hand, it also seems that for some students placing the focus on suprasegmental features has sometimes rendered the readings unintelligible.

However, the lack of homogeneity in the ratings can also be explained by the differences between both tasks (a possibility the evaluators also suggested). First of all, the students chose the texts individually and some texts might have been more difficult than others. By contrast, the FSs probably had a more similar level of difficulty for every student. Second, the readings were imitations of scenes from films or TV series and were therefore harder to understand because the evaluators listened to them with no visual support or contextualization of the scene which the students were imitating. On the contrary, the speeches consisted of students talking about a topic of their own choice and were therefore solely based on oral language. This might partly explain why some students were more intelligible in the FSs despite sounding more Spanish. Also, the language in the readings often contained features of colloquial speech (elisions, unfinished sentences, hesitation marks, repetitions etc.) which made both their imitation and their understanding really difficult. Finally, imitating involves specific (actor-like) skills which some students might lack and therefore do better when speaking since they are just being themselves. 


\subsection{Will the students find the reading aloud activity useful as a tool to improve their pronunciation?}

As explained earlier, after the reading and speaking tasks were finished, all participants had to respond to a usefulness survey with their impressions about the impact of the training through the imitation of oral texts. They had to choose between 1 (not useful); 2 (a bit useful): 3 (quite useful); 4 (very useful). The group average on the usefulness of the reading task was 3.6/4. Figure 4 shows individual results.

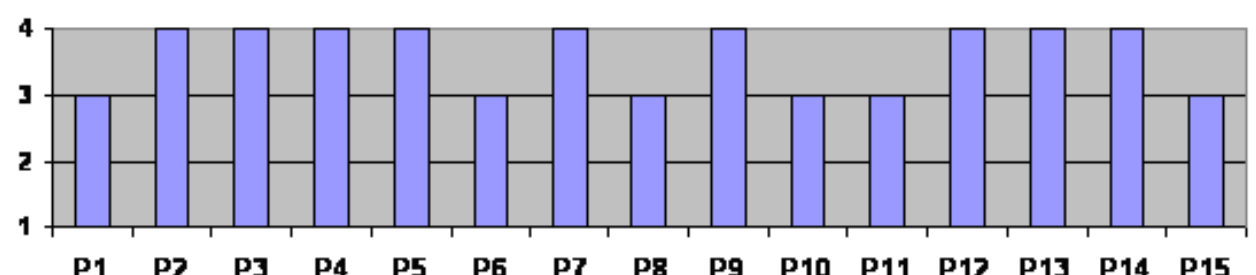

DUSEFULNESS OF READING ALOUD

Figure 4: Individual results: Usefulness survey (1-4 scale).

As can be seen in Figure 4, all participants defined the task as «quite useful» (score 3) or «very useful» (score 4). In conclusion, the participants were very satisfied with the reading task as a training tool for the improvement of pronunciation. Also, in the subsequent discussion, the whole group confirmed that they had found the task not only useful but also very challenging, motivating and entertaining. They also explained that the activity had forced them to focus on English pronunciation very thoroughly and that they had never before realized how important intonation was. They said that the task had also helped them to become aware of their pronunciation problems. Finally, three students added that they had felt quite embarrassed when imitating the texts and two explained that the task had helped them to notice accent differences.

\section{CONClusions AND PEDAgogical IMPLICATIONS}

If we look at students' opinions, the results were extremely positive since all students felt very satisfied with the imitation practice. If we look at their scores, the results were also positive but only moderately positive: (i) the students' pronunciation was only slightly better in the second reading and (ii) the speeches were more intelligible but did not seem to have more English-like suprasegmental features.

Despite this moderate improvement, we believe that our results are interesting enough to open up lines for future research to explore these preliminary impressions. First of all, some methodological limitations of the present work could be overcome in future works. It would be very interesting to record an initial FS to be able to compare it with the final one, to see whether FS improves throughout the course. The problem of intelligibility in the imitations might have been partly caused by the fact that the evaluators only listened 
to the recordings without watching the original scenes from which the extracts had been taken. This could be avoided by either watching the scenes first or by using radio recordings. Also, using only one extract to imitate (selected by the teacher) could solve the problem of students facing different levels of difficulty when they choose the texts on their own.

On the other hand, it would be necessary to extend this training to see what happens in the long run with extended reading aloud practice and with larger pools of participants. Future research could also explore to what extent, as it has been claimed, this type of task helps learners to establish correct connections between written and oral English. Finally, it would be extremely interesting to try this task out with participants from different language backgrounds, different ages, different levels, different learning contexts, etc.

Finally, as a result of learner feedback and reflection by the researcher some potential pedagogical implications can be drawn. To encourage teachers to try this reading activity with their students, we would like to enumerate some of them:

- The task raises students' (segmental and suprasegmental) phonological awareness.

- The task raises students' awareness of different English accents.

- The use of extracts from films and TV series is very motivating and provides samples of natural English.

- The task helps with listening comprehension. Although we did not analyse the improvements in discrimination, understanding and pronouncing usually go hand in hand.

- The task is useful as a life-long learning tool.

- The task is good for autonomous learning.

- The task offers logistical advantages. It is not very demanding for teachers since it does not require too much time to prepare, especially nowadays when recordings are easily accessible from different sources.

In this study we have attempted to encourage the teaching of pronunciation in EFL classrooms testing one specific activity: reading aloud imitating English oral texts. Results have shown that this activity seems to have positive effects on pronunciation and motivation. Also, it is an activity that all teachers could integrate in their EFL classroom practices without the need of specific training, materials etc. Therefore, we strongly believe that the cautiously positive results we have found together with the feasibility of the task, make reading aloud imitating native texts worth a try. If pronunciation has been often described as the Cinderella of language teaching this experiment has set off in the pursuit of at least one well-fitting shoe!

\section{AcKnowledgments}

This study was supported by the grant HUM2006-09775-C02-01/FILO awarded by the Spanish Ministry of Science and Technology. This grant is hereby gratefully acknowledged. 


\section{REFERENCES}

Akamatsu, N. (1999). «The effects of first language orthographic features on word recognition processing in English as a second language», in Reading and Writing, 11: 381-403.

Akamatsu, N. (2002). «A similarity in word-recognition procedures among second language readers with different first language backgrounds», in Applied Psycholinguistics, 23: 117-133.

Anderson-Hsieh, J., Johnson, R. and Koehler, K. (1992). «The relationship between native speaker judgments of nonnative pronunciation and deviance in segmentals, prosody, and syllable structure», in Language Learning 42: 529-555.

Avery, P, and Ehrlich, S. (1992). Teaching American English Pronunciation. Oxford: Oxford University Press.

Barnes, N. (1988). «Does intonation matter?», in Speak OUT! 3, 17 (Journal of the IATEFL Phonology SIG).

Barrera Pardo, D. (2004). «Can Pronunciation Be Taught? A Review of Research and Implications for Teaching» in Revista Alicantina de Estudios Ingleses 17: 6-38.

Beaken, M. (2009). «Teaching discourse intonation with Narrative», in ELT Journal 63, 4: 342-352.

Birch, B. (2002). English L2 Reading: Getting to the Bottom. Mahwah, NJ: Lawrence Erlbaum Associates.

Boyle, J. (1987). «Perspectives on stress and intonation in language learning» in System, 15, 189195.

Brazil, D. (1997). The Communicative Value of Intonation in English. Cambridge: Cambridge: University Press.

Brown, A. (ed.)(1991). Teaching English Pronunciation: A Book of Readings. London: Routledge. Brumfit, C.J. and Johnson, K. (ed.)(1979). The communicative approach to language teaching. Oxford: Oxford University Press.

Bryson, B. (1990). Mother Tongue ( The English Language). London: Penguin.

Celce-Murcia, M., Brinton, D.M. and Goodwin, J.M. (1996). Teaching Pronunciation. A Reference for Teachers of English to Speakers of other Languages. Cambridge: Cambridge University Press.

Chun, D. (1988). «The neglected role of intonation in communicative competence and proficiency», in Modern Language Journal, 72: 295-303.

Chun, D.M. (2002). Discourse intonation in L2: From theory and research to practice. Amsterdam: Benjamins.

Dalton, C. and Seidlhofer, B. (1994). Pronunciation. Oxford: Oxford University Press.

Derwing, T. and Munro, J. (2005). «Second Language Accent and Pronunciation Teaching: A ResearchBased Approach», in TESOL Quarterly, 39, 3: 379-397.

Derwing, T. and Rossiter, M. (2003). «The effects of pronunciation instruction on the accuracy, fluency and complexity of L2 accented speech», in Applied Language Learning, 13: 1-18.

Dwyer, M.A. (1983). «Some strategies for improving reading efficiency», in Forum, 12, 3: 5-10.

Gabrielatos, C. (2002). «Reading loud and clear: Reading aloud in ELT», in ERIC, ED477572.

Gardner, R.C. (1982). «Language attitudes and language learning», in E. Boudhard Ryan and H. Giles (eds.), Attitudes towards language variation. London: Edward Arnold, 132-147.

Gardner, R.C. and Lambert, W.E. (1959). «Motivational Variables in Second-Language Acquisition», in Canadian Journal of Psychology, 13: 266-272.

Gass, S. M., and Selinker, L. (eds.)(1983). Language transfer in language learning. Rowley, MA: Newbury House.

Gibson, S. (2008). «Reading aloud: a useful learning tool?», in ELT Journal, 62: 29-36. 
Gilbert, S. (2008). Teaching Pronunciation. Using the Prosody Pyramid. New York: Cambridge University Press.

Hamada, M. and Koda, K. (2008). «Influence of first language orthographic experience on second language decoding and word learning», in Language Learning, 58, 1: 1-31

Hughes, A. (1991). Testing for Language Teachers. Cambridge: Cambridge University Press.

Jenkins, J. (2000). The Phonology of English as an International Language. Oxford: OUP.

Jenkins, J. (2004). «Research in teaching pronunciation and intonation», in Annual Review of Applied Linguistics, 24: 109-125.

Kellerman, E. and Sharwood Smith, M. (eds.)(1986). Crosslinguistic influence in second language acquisition. New York: Pergamon Press.

Koda, K. (1989). «Effects of L1 orthographic representation on L1 phonological coding strategies», in Journal of Psycholinguistic Research, 18: 201-222.

Koda, K. (1990). «The use of L1 reading strategies in L2 reading», in Studies in Second Language Acquisition, 12: 393-410.

Koda, K. (1999). «Development of L2 intraword orthographic sensitivity and decoding skills», in Modern Language Journal, 83: 51-64.

Koda, K. (2000). «Cross-linguistic variations in L1 morphological awareness», in Applied Psycholinguistics, 21: 297-320.

Koren, S. (1995). «Foreign language pronunciation testing: a new approach», in System, 23, 3: 387400.

Lázaro Ibarrola, A. (2007). «Enseñanaza de la lectura a través de «phonics» en el aula de Lengua Extranjera en Educación Primaria», in Porta Linguarum, 8: 153-167, available from http:/ /www.ugr.es/local/portalin, accessed 13 March, 2010.

Leather, J. (1983). «Second-language pronunciation learning and teaching», in Language Teaching Abstracts, 16: 198-219.

Lieberman, P. (1967). Intonation, perception and language. Cambridge, MA: MIT Press.

Moyer, A. (1999). «Ultimate attainment in L2 phonology: The cricitical factors of age, motivation, and instruction», in Studies in Second Language Acquisition, 21: 1-108.

Munro, M.J. and Derwing, T.M. (1995). «Foreign accent, comprehensibility, and intelligibility in the speech of second language learners», in Language Learning, 45: 73-97.

Munro, M. J. and Derwing, T. M. (1998). «The effects of speaking rate on listener evaluations of native and foreign-accented speech», in Language Learning, 48: 159-182.

Munro, M.J. and Derwing, T.M. (2001). «Modeling perceptions of the accentedness and comprehensibility of L2 speech: The role of speaking rate», in Studies in Second Language Acquisition, 23: 451-468.

Murphy, J. (1997). «Phonology courses offered by MATESOL programs in the U.S», in TESOL Quarterly, 31: 741-764.

Pennington, M. (1989). «Teaching pronunciation from the top down», in RELC Journal, 20: 20-38.

Pennington, M. and Richards, J. (1986). «Pronunciation revisited», in TESOL Quarterly, 20: 207225.

Perfetti, C.A. and Liu, Y. (2005). «Orthography to phonology and meaning: Comparisons across and within writing systems», in Reading and Writing, 18, 193-210.

Richards, J. and Rodgers, T. (2001). Approaches and methods in language Teaching (2nd ed.). Cambridge: Cambridge University Press.

Roach, P. (1991)(2 $2^{\text {nd }}$ ed.). English Phonetics and Phonology: A Practical Course. Cambridge: Cambridge University Press.

Samuda, V. (1993). «Pronunciation textbooks», in TESOL Quarterly, 27: 757-758. 
Stevick, E. (1989). Success with Foreign Languages: Seven who achieved it and What Worked for them. Hemel Hempstead: Prentice Hall International.

Trofimovich, P. and Baker, W. (2006). «Learning second-language suprasegmentals: Effect of L2 experience on prosody and fluency characteristics of L2 speech», in Studies in Second Language Acquisition, 28: 1-30.

Underhill, N. (1987). Testing Spoken Language. A handbook of oral testing techniques. Cambridge: Cambridge University Press.

Walker, R. (1999): «Proclaimed and perceived wants and needs among Spanish teachers of English», in Speak Out! (Newsletter of the IATEFL Pronunciation Special Interest Group), 24: 2532.

Wallace, C. (1992). Reading. Oxford University Press.

Wang, M., Koda, K. and Perfetti, C.A. (2003). «Alphabetic and nonalphabetic L1 effects in English word identification: A comparison of Korean and Chinese English L2 learners», in Cognition, 87: 129-149.

Widdowson, H.G. (1978). Teaching Language as Communication. Oxford: OUP.

http://www.public.iastate.edu/ jlevis/SPRIS/, Interest Section for Speech, Pronunciation and Listening, accessed 8 March, 2010.

http://www.coe.int/T/DG4/Linguistic/CADRE_EN.asp, Common European Framework of Reference for Languages, accessed 8 March, $20 \overline{1} 0$. 